\title{
Prostate Cancer Pathologic TNM Finding v6
}

National Cancer Institute

\section{Source}

National Cancer Institute. Prostate Cancer Pathologic TNM Finding v6. NCI Thesaurus. Code C48235.

A pathologic finding about one or more characteristics of prostate cancer, following the rules of the TNM AJCC v6 classification system. TNM pathologic findings are based on clinical findings supplemented by histopathologic examination of one or more tissue specimens acquired during surgery. 